\title{
Efficient Risk-Taking and Regulatory Covenant Enforcement in a Deregulated Banking Industry
}

\author{
Robert DeYoung \\ Federal Reserve Bank of Chicago \\ 230 South LaSalle Street \\ Chicago, IL 60604 \\ robert.deyoung@chi.frb.org \\ 312-322-5396 \\ Joseph P. Hughes \\ Department of Economics \\ Rutgers University \\ New Brunswick, NJ 08901-1248 \\ jphughes@ rci.rutgers.edu \\ 732-932-7517 \\ Choon-Geol Moon \\ College of Business and Economics \\ Hanyang University \\ 17 Haengdang-Dong, Seongdong-Gu \\ Seoul 133-791, KOREA \\ mooncg@unitel.co.kr \\ 82-2-290-1035
}

December 1999

The opinions expressed in this paper are those of the authors and do not necessarily reflect the views of the Federal Reserve Bank of Chicago, the Board of Governors of the Federal Reserve System, or their staffs. The authors thank Lee Cross, Kevin Jacques, Simon Kwan, Bill Lang, Tom Lutton, Joe Mason, Sherrill Shaffer, Paul Wilson, seminar participants at the Federal Reserve Board, and two anonymous referees for their helpful comments. 


\title{
Efficient Risk-Taking and Regulatory Covenant Enforcement \\ in a Deregulated Banking Industry
}

\begin{abstract}
Over the past two decades, a variety of deregulatory measures have increased competition in the U.S. commercial banking industry. While increased competitive rivalry creates incentives for banks to operate more efficiently, it also creates incentives for banks to take additional risk, potentially threatening the safety of banking and payments system. Commercial bank regulators have responded to this increased potential for risk-taking by formally linking bank supervision and regulation to the level of risks that banks take. In this study we analyze the safety and soundness (CAMEL) ratings assigned by bank supervisors to commercial banks, and search for evidence that these ratings reflect not just the level of risk taken by banks, but also the risk-taking efficiency of those banks (i.e., whether taking an increased level of risk generates higher expected returns). We find that supervisors do distinguish between the risk-taking of efficient banks and the risk-taking of inefficient banks, and that they permit efficient banks more latitude in their investment strategies than inefficient banks. However, we also find that supervisors maintain incentives for both efficient and inefficient banks to manage their risk more efficiently.
\end{abstract}




\section{Introduction}

Over the last twenty years, a variety of measures aimed at deregulating U.S. commercial banking have been enacted. For example, intrastate and interstate branching restrictions have been substantially relaxed, interest rate ceilings on time deposits have been abolished, and thrift institutions have been permitted to enter product markets previously reserved for commercial banks. While the increased competition resulting from such measures can encourage banks to operate more efficiently, it can also increase banks' incentives to take risk, which can potentially threaten the safety of banks and the payments system.

Historically, barriers to competition supported banks' profitability, and the capitalized value of these profits increased the value of banks' charters. These high profits provided an important incentive for banks to limit their risk-taking to avoid insolvency and losing their valuable charters. But as increased competition has eroded both bank profits and charter values, banks have attempted to enhance their expected earnings by taking additional risk. The competition-induced incentives to increase risk can reenforce the already existing moral hazard incentives provided by the deposit insurance and discount window safety nets, which historically have not fully priced the risks that banks take. Thus, in a deregulated banking system, bank regulators face the challenge of monitoring and controlling banks' risk-taking, while at the same time not restricting competitive forces which can discipline banks and improve industry efficiency.

At the center of this regulatory challenge are banks' demand deposits -- an unique form of demandable debt used by banks to finance their operations, and a key part of the economy's payments system. The regulation and supervision of banks' risk-taking protects the safety of bank deposits and, hence, the payments system. To a large degree, the role played by bank regulators is analogous to that of writing and monitoring debt covenants for the depositors, whose debt is not protected by standard covenants. ${ }^{1}$ Safety and soundness covenants, such as minimum capital ratios and loan concentration limits, constrain banks' menu of feasible riskreturn choices. When these safety and soundness covenants become binding, regulators can enforce remedial covenants, such as restricting asset growth or raising additional equity capital, that constrain the actions of banks further. Because regulatory covenant enforcement can impose substantial costs on banks that encounter financial distress, it provides an important incentive for banks to limit risk-taking. ${ }^{2}$ If administered carefully, the threat of covenant enforcement can

\footnotetext{
${ }^{1}$ See Dewatripont and Tirole (1994, p. 87) for an analysis of how bank regulation resembles debt covenant agreements.

${ }^{2}$ Smith and Stulz (1985) demonstrate that the financial distress costs created by covenant enforcement make trading expected return for reduced risk a value-maximizing business strategy.
} 
appropriately balance the risk-increasing incentives created by increased competition and mispriced safety nets.

Not all risk-taking is imprudent, and some banks are better at risk-taking than others. Banks that are more efficient risk-takers earn higher expected returns for the risks they take; that is, they enjoy a better menu of risk-return choices. Banks that are efficient risk-takers have a lower probability of experiencing financial distress, and have a higher probability of recovering from adverse exogenous circumstances that produce financial distress. Thus, effective regulation and supervision of commercial banks will distinguish efficient risk-taking from inefficient risktaking, and will discourage the latter. In response to the risk-increasing incentives created by deregulation and increased competition, over the past decade bank regulators have introduced a number of measures that formally link the regulation of commercial banks to the level of risks they take. Risk-based capital requirements and risk-based deposit insurance premia are two prominent examples. More recently, regulators have changed the procedures for their annual examinations of bank safety and soundness to include an explicit assessment of banks' ability to manage risk.

In this study we look for evidence that, in formally linking regulation to risk, commercial bank regulators distinguish between a bank's level of risk and its efficiency at risk-taking. We ask, in effect, do bank regulators treat the risk-taking of efficient banks differently than the risktaking of inefficient banks? Do regulators afford efficient banks more latitude in their investment strategies than inefficient banks? Do regulators create incentives for banks to improve the efficiency of their risk-taking? Our evidence answers, "Yes," to each of these questions. Our findings suggest that the increased opportunities for risk-taking the deregulated banking industry are not encouraged equally for all banks. We also find that, despite this differential treatment of banks, regulators provide incentives for both efficient and inefficient banks to manage risk more efficiently.

To investigate these questions we focus on banks' CAMEL ratings, the annual supervisory assessment of a bank's overall financial condition and its compliance with safety and soundness covenants. Because these ratings reflect the likelihood that supervisors will enforce remedial covenants and, in doing so, impose distress costs on banks, the ratings provide our investigation with the critical clues needed to look for differences in regulatory incentives for relatively efficient and inefficient risk-takers to trade return for reduced risk.

We use a three-step procedure to investigate these questions. In the first step, we employ a structural model of production to obtain estimates of expected return and risk for the 356 national banks in our sample. Our model, developed by Hughes, Lang, Mester, and Moon (1995, 
1996, 1999) and Hughes and Moon (1995), allows bank managers to trade expected return for reduced risk. The model employs the Almost Ideal Demand System (Deaton and Muellbauer, 1980) to recover managers' preferences for expected return and risk from cross-sectional price and production data for 1994. Using a production-based approach allows us to include both privately and publicly held banks in our tests and also allows us to estimate each bank's productive inefficiency. Each bank's expected return-risk combination establishes one point on its own risk-return frontier. In the second step, we fit a stochastic, envelope frontier to the 356 expected return-risk combinations. This produces an overall, best-practice risk-return frontier for all banks in the sample. We measure each bank's risk-return efficiency by its distance from this frontier. Finally, to consider how bank supervisors evaluate banks' risk-return trade-offs, we estimate an ordered logit model that relates each bank's CAMEL rating to its expected return, its risk, its risk-return inefficiency, and its size. By controlling for a bank's size and its risk-return choice, we can isolate the effect of its efficiency at risk-taking on its CAMEL rating. That is, we can reveal whether the likelihood that regulators enforce remedial covenants, and thus provide incentives for banks to exchange return for reduced risk, is related to the efficiency with which banks take risk.

The evidence we find is consistent with our hypothesis that a bank's regulatory treatment is influenced by how efficiently it manages risk. Among the least efficient banks in our sample, banks that take extra risk for a higher expected return are assigned worse CAMEL ratings, and the larger the bank, the stricter the standard that is applied to it. In contrast, among the most efficient banks in our sample, CAMEL ratings were related only to the degree of banks' efficiency, not to their risk-return choice or to their size. On one hand, our results suggest that if banks are relatively efficient at risk-taking, examiners provide incentives for further efficiency improvements, but tend not to discourage the "prudent" risks taken by these banks. On the other hand, our results also suggest that if banks are relatively inefficient at risk-taking, examiners not only penalize the choice of a higher risk-higher return strategy, but penalize size as well, perhaps because larger inefficient banks pose a greater threat to the payments system.

The principal contributions of our study are the following. First, we show that banks' efficiency at managing risk as well as banks' ex ante risk-return choices are important for explaining bank supervisors' assessments of their safety and soundness. Thus, the riskincreasing incentives created by increased competition may not compromise bank safety when bank supervision distinguishes efficient from inefficient risk-taking and discourages the latter. Second, the success of these measures in explaining CAMEL ratings demonstrates that it is important to account for risk when measuring banks' profit efficiency. Although there is a large 
literature on efficiency measurement in banking, only a handful of studies explicitly incorporate ex ante risk. ${ }^{3}$ Finally, we introduce the techniques of efficiency measurement that incorporate risk to the literature on CAMEL ratings, which has to date generally focused on the relationship between CAMEL ratings and the market value of banks' debt and equity.

Section I that follows describes how the regulation of commercial banks in the United States influences the financial distress costs that they face and how distress costs affect their value-maximizing choice of expected return and return risk. Section II briefly reviews some of the literature on the effect of financial distress costs on bank risk-taking. Section III describes how a bank's exam scores, the CAMEL ratings, reflect the safety and soundness objectives of bank regulators. We present our three-step procedure for estimating expected return, risk, and efficiency in sections IV, V, and VI. Because each stage of our analysis generates results that are interesting in their own right, we present the intermediate results at the end of each of these three sections. Lastly, we summarize our findings in section VII and draw conclusions about the incentives that regulatory monitoring and covenant enforcement provide for banks to trade expected return for reduced risk and to manage risk efficiently.

\section{The Effect of Distress Costs on Bank Risk-Taking}

Trading expected return for reduced risk is a value-maximizing strategy whenever the occurrence of large losses would expose a firm to a costly episode of financial distress. Financial distress costs can include (i) constraints imposed on the firm when its debt covenants become binding; (ii) higher costs of borrowing that lead to suboptimal investment policy; (iii) the disruption of valuable relationships with customers and suppliers; and (iv) the sale of assets at depressed prices.

Financial distress costs play an important role in commercial banking. Not only are banks highly levered firms, but the nature of their leverage is unique in that a substantial portion of bank debt is demandable, and this demandable debt (i.e., bank deposits) is part of the economy's payments system. Banks' ability to monitor these demand deposits gives them an informational advantage over nonbank lenders in assessing credit risk and monitoring borrower behavior. ${ }^{4}$ However, this informational advantage also means that the quality of banks' assets is not readily observable to outsiders, so depositors have the incentive to demand their funds when a bank

\footnotetext{
${ }^{3}$ See Berger and Mester (1997) for a review of this literature. Hughes and Moon (1995) develop a production-based technique of efficiency measurement that accounts for ex ante risk and Hughes, Lang, Mester, and Moon $(1996,1999)$ apply this technique to interstate banking and to bank consolidation.

${ }^{4}$ See, for example, Kane and Malkiel (1965), Black (1975), Fama (1985), and James (1987).
} 
appears to be taking excessive risks. Furthermore, because a run on one bank can spread to other banks, risk-taking at an individual bank can potentially disrupt the payments system. ${ }^{5}$ Thus, episodes of financial distress are likely to impose a number of costs on commercial banks, including liquidity crises, the loss of valuable customer relationships, and, in the extreme case of insolvency, the loss of a valuable charter. Given the costs of these scenarios, banks may well find that trading current expected return for reduced risk--and thereby reducing the likelihood of distress and its expected costs--is a value-maximizing strategy.

Commercial banking is a highly regulated industry, and actions taken by bank regulators can strongly influence the distress costs at banks. Regulators monitor and constrain bank risk-taking, place limits on banks' investment activities and production plans, and have the power to remove bank officers and revoke bank charters. The regulatory process is analogous to writing debt covenants to control moral hazard and to enforcing these covenants when they become binding. Hence, the regulatory process guards the interests of demandable debtholders, who are not explicitly protected by the standard covenants of debt contracts. The regulatory process also protects the interests of the deposit insurer and insures the safety of the payments system.

Bank examinations are an integral part of monitoring and enforcing regulatory covenants. At the close of each examination, bank examiners assign a numerical rating of the bank's safety and soundness. This rating is based on objective measures of the bank's current condition and recent performance, and also reflects the examiners' subjective assessment of the bank's ability to respond to unfavorable future economic conditions. A bank's examination rating quantifies the likelihood that the supervisor will take action (i.e., enforce covenants) to protect depositors, the deposit insurer, and the payments system. In some cases the connection between the exam rating and covenant enforcement is direct, e.g., exam ratings enter into the formulae that determine capital requirements and deposit insurance premia. In other cases the connection is less direct, e.g., banks with poor exam ratings get examined more frequently and more rigorously.

Because the government has the power and the mandate to monitor banks' risk-taking, to enforce remedial covenants on banks that take imprudent amounts of risk, and to impose distress costs in the process, bank regulation and supervision may induce banks to choose less risky business strategies. When supervisors also distinguish the efficiency of banks' risk-taking from the level of their risk and impose higher expected distress costs on inefficient risk-takers, they give inefficient banks an incentive to become more efficient while they discourage inefficient risk-taking.

\footnotetext{
${ }^{5}$ See Freixas and Rochet (1997), especially chapter 7.
} 
Banks that trade expected return for lower risk and that are more efficient at risk-taking reduce their likelihood of failure. The bank in Figure 1 that chooses to produce at point A on its risk-return frontier rather than point B has traded return for reduced risk and has lowered its probability of failure. Risk-return combinations with the same probability of failure are indicated in Figure 1 by the rays, which represent constant z-scores. ${ }^{6}$ Because rays to the right represent lower z-scores and higher probabilities of insolvency, choosing to produce at A rather than B lowers the probability of financial distress and failure.

Unlike individual investors who purchase portfolios of market-produced assets and who face the same efficient risk-return trade-off, banks employ the informational edge afforded by their demand deposits to produce information-intensive assets, or loans, that constitute much of their portfolios. Since many of these loans are not generally marketable, individual banks do not face identical risk-return trade-offs. The bank in Figure 1 whose frontier passes through point $\mathrm{C}$ may not be as well diversified geographically as the bank whose frontier includes A and B. Or, it may not manage risk and generate expected return as well. In any case, point $\mathrm{C}$ lies on the lower of the two z-score rays, so it is obvious that the inefficiencies that force a bank to operate at $\mathrm{C}$ rather than A also increase the probability of distress and failure.

Examination ratings summarize a bank's performance and reflect the likelihood that the supervisor will respond to poor performance by enforcing remedial covenants. In this study we investigate whether regulators assign better exam ratings to banks that choose point $\mathrm{A}$ in Figure 1 over point B, sacrificing expected return for reduced risk and, hence, a lower probability of distress and failure. Similarly, we ask whether efficient banks at point A, with their higher expected returns and lower probabilities of distress, receive better exam ratings than inefficient banks at point $\mathrm{C}$. To the extent that inefficiency and higher risk-return choices are associated with poorer exam ratings, the threat of remedial covenant enforcement will be greater and, hence, banks' incentives to trade expected return for reduced risk and to improve their efficiency will increase. Finally, we compare banks at points B and C and ask whether the more efficient banks at point $\mathrm{B}$ receive better exam ratings despite having the same likelihood of insolvency. To the extent that supervisors distinguish inefficiency from the level of risk and impose higher expected distress costs on inefficient risk-taking, supervisors both discourage inefficient risk-taking and

\footnotetext{
${ }^{6}$ A bank's z-score is the sum of its equity capital and expected profit, divided by the standard deviation of profit, and thus varies negatively with the bank's probability of insolvency. Equivalently, the z-score can be expressed as one plus the expected return on equity, divided by the standard deviation of return. When the z-score is a constant, say $k$, the expected return $=\left(k^{*}\right.$ standard deviation -1$)$. Thus, loci of constant $z$-scores are rays whose slope equals $k$ and which emanate from -1 on the y-axis.
} 
they provide an incentive to improve efficiency.

\section{Evidence of the Effect of Distress Costs on Bank Risk-Taking}

A number of recent studies have found relationships between banks' incentives to exchange return for reduced risk and the economic and market conditions under which banks operate. The studies have posited or established links between banks' risk-return trade-offs and the degree of market competition, the opaqueness of bank assets, banks' unusual liquidity risk, and the necessity of holding a valuable bank charter in order to be able to offer demand deposits.

The increased level of competition in the post-deregulation banking industry has changed the incentives facing banks in several ways. Studies by Akhavein, Berger, and Humphrey (1997), DeYoung, Hasan, and Kirchhoff (1998), Hughes, Lang, Mester, and Moon (1999), and others suggest that the competition induced by deregulation has provided banks with an incentive to operate more efficiently. But increased competition can also increase banks' incentives to take risk, which can potentially threaten the safety of banks and the payments system. Keeley (1990) finds evidence that increasing competition in U.S. banking over the last several decades has eroded the value of a commercial bank charter and, consequently, has led banks to take greater risks to improve their expected earnings. A more recent study by Demsetz, Saidenberg, and Strahan (1996) draws similar conclusions. Kwan and Eisenbeis (1996) find that banks exhibiting large amounts of cost inefficiency earned low ex post returns, but tended to choose high-risk business strategies, and hypothesize that these inefficient banks had relatively low charter value. Finally, competition-induced incentives to increase risk may be reenforcing the existing moral hazard incentives provided by the deposit insurance safety net (Merton 1977 and Marcus 1984).

Banks with better asset quality can lower the cost of their uninsured, borrowed funds and reduce the probability of liquidity crises if they can credibly signal the quality to less informed creditors. To test this hypothesis, Lucas and McDonald (1992) develop a model in which value-maximizing banks signal asset quality with their holdings of riskless government securities. Hughes and Mester (1998) explore the role of equity capital as a signal of asset quality. Employing 1990 data on large U.S. banks, they estimate a cost function that is conditioned on the level of equity capital. Central to their model is the bank's demand for equity capital, which is derived from a managerial utility function so that banks do not necessarily choose the cost-minimizing level of capital. They find that equity capital behaves, not as an input, (i.e., a source of funds), but as a signal of both asset quality and the amount of resources devoted to risk management. 


\section{Interpreting CAMEL Ratings}

Regulatory monitoring and covenant enforcement might enhance incentives to trade return for reduced risk. The majority of commercial banks are examined annually for safety and soundness either by the Office of the Comptroller of the Currency, the Federal Deposit Insurance Corporation, the Federal Reserve System, or by a state regulator. The most important product of the annual exam is the CAMEL rating, which is a composite of five separate performance components: capital adequacy (C), asset quality (A), management or administration (M), earnings (E), and liquidity (L). Each of these five performance components ranges in whole numbers from 1, indicating "strong performance," to 5, indicating "unsatisfactory" performance. The composite CAMEL rating also ranges from 1, which indicates that the bank is "basically sound in every respect," to 5, which warns of an "extremely high, immediate or near-term probability of failure." 7

Examiners determine the $\mathrm{C}, \mathrm{A}, \mathrm{E}$, and $\mathrm{L}$ ratings based on a combination of objective information and subjective judgment, with the primary focus on the former. Ratings in these first four areas are based mostly on quantifiable measures of financial performance such as capital ratios, profitability ratios, earnings retention, nonaccruing and nonperforming loans, and deposit volatility. In contrast, the $\mathrm{M}$ rating is based to a large degree on the examiners' subjective evaluation of nonquantifiable phenomena such as the adequacy of procedures and policies, the demonstrated ability of managers to respond to unforeseen developments in the four other performance dimensions, and any special circumstances that may be influencing the bank's performance. $^{8}$

Since many supervisory actions taken by regulators reflect the bank's current CAMEL rating, not all banks receive the same supervisory treatment. These actions are aimed at maintaining the solvency of the bank, and, although regulators often allow banks with CAMEL ratings of 4 and 5 to fail, this general focus on safety and soundness suggests that bank examiners may favor banks that trade return for reduced risk.

Because exam ratings are not disclosed to the public, most academic research using exam

\footnotetext{
${ }^{7}$ Although the composite CAMEL rating is highly correlated ex post to each of the five performance ratings, it is not an arithmetic combination of the five ratings. In addition, a sixth performance rating, sensitivity to market risk (S), was added after our study was completed.

${ }^{8}$ A detailed description of the conditions considered by national bank examiners when assigning the CAMEL ratings can be found in the "Uniform Financial Institutions Rating System," Examining Circular 159, Office of the Comptroller of the Currency (1979).
} 
ratings tests whether and how quickly financial markets discover this private information. ${ }^{9}$ In a recent study closely related to our investigation, Hall, Meyer, and Vaughan (1997) regressed BOPEC ratings (the ratings that reflect regulators' assessment of bank holding company risk) on a set of financial ratios for holding companies from the period 1988-93. The authors also regressed estimates of risk from a two-factor market model (the market's assessment of bank holding company risk) on the same variables. Regulatory risk assessments were strongly related to credit risk as well as capital levels, while the market risk assessments were strongly related only to credit risk. The authors conclude that bank regulators have a greater aversion to the risk of insolvency than do bank investors and are therefore more likely to assign worse exam ratings to banks that take extra risk for more return.

\section{Estimating Expected Return and Risk}

In order to include banks in our sample that are privately as well as publicly held and in order to measure banks' productive inefficiency, we estimate expected return and return risk from a model of bank portfolio production developed by Hughes, Lang, Mester, and Moon (1993, $1995,1996,1999)$ from earlier work by Hughes $(1989,1990)$, that allows bank managers to choose levered portfolio production plans that trade profit for reduced risk. Standard models of bank production assume that managers employ the combination of inputs and outputs that maximizes profit. Hence, these models do not allow for the possibility that managers would choose to trade profitability for a reduced risk of financial distress and insolvency. In our model of bank production, however, managers choose their most preferred levered portfolio production plan, which is the combination of inputs and outputs that maximizes their utility. This utility-maximizing production plan may or may not be the profit-maximizing plan.

Hughes and Moon (1995) show that the utility function's ranking of production plans is equivalent to a ranking of subjective probability distributions of profit that are conditional on the production plan. The connection between production plans and their implied probability distributions of profit follows from managers' beliefs about the probabilities of future economic states of the world and their beliefs about how profits will be generated by production plans in these future economic states. These beliefs link each production plan with a subjective, conditional probability distribution of profit and provide the foundation for managers' rankings of

\footnotetext{
${ }^{9}$ See Hirschhorn (1987); Cargill (1989); Simons and Cross (1991); Gilbert (1993); Berger and Davies (1994); Dahl, Hanweck, and O'Keefe (1996); O'Keefe and Dahl (1996); Flannery and Houston (1997); DeYoung, Flannery, Lang, and Sorescu (1998); Berger, Davies, and Flannery (1998); and Cole and Gunther (1998).
} 
production plans. These rankings can be summarized by a utility function defined over production plans or, equivalently, defined over subjective, probability distributions that are conditional on the production plans. These rankings reflect not only the managers' beliefs about future economic conditions and their profit implications, but also the managers' risk preferences.

In the absence of distress costs, a value-maximizing manager ranks each production plan solely by the first moment of its implied conditional distribution of profit. Hence, the manager's highest ranked plan is the one that maximizes expected profit. In the presence of distress costs, however, maximizing the value of the bank requires the manager to trade expected current return for reduced risk. Thus, to rank a production plan which factors in consideration of distress costs, the manager will use, not just on its first moment (expected profit), but also its second moment (variance of profit) and, perhaps, higher moments of its conditional distribution of profit.

Hughes, Lang, Mester, and Moon (1993, 1995, 1996, 1999) adapt the Almost Ideal Demand System to represent these managerial preferences and use it to recover managers' rankings of production plans from data on input and output prices as well as other components of the economic environment. Hughes and Moon (1995) demonstrate how the most preferred production plan obtained in this fashion can be compactly expressed as the most preferred expected rate of return on equity (a first moment measurement) and the most preferred return risk (a second moment measurement) for each bank in the sample. They estimate a best-practice risk-return frontier for the banking industry as the stochastic upper envelope of the expected return and risk pairs of the individual banks, and identify each bank's risk-return efficiency as its "noise-corrected" distance from this frontier.

\section{A. Producing an Information-Intensive, Levered Asset Portfolio}

Banks hold a portfolio of government securities and information-intensive loans. (Note that loans are produced outputs while securities are purchased outputs.) The loans are produced with labor and physical capital, both of which are used to gather information, assess credit risk, write loan contracts, monitor borrowers' behavior, and deal with borrowers' experiencing financial distress. The portfolio is funded with equity capital and levered with demandable debt and other borrowed funds. We designate the output or asset vector, $\boldsymbol{y}$; the inputs that include labor, physical capital, demandable debt, and other borrowed funds, $\boldsymbol{x}$; and equity capital, $k$. The bank's levered portfolio production plan is given by $(\boldsymbol{y}, \boldsymbol{x}, k)$. The transformation function, $T(\boldsymbol{y}, \boldsymbol{x}, k) \leq 0$, defines the feasible set of levered portfolio production plans.

Managers are assumed to have well-behaved preference orderings defined over profit, $\pi$, and the production plan, $(\boldsymbol{y}, \boldsymbol{x}, k)$, that can be represented by the utility function, $U(\pi, \boldsymbol{y}, \boldsymbol{x}, k)$. If 
there are no distress costs and managers simply maximize profit, only profit has marginal significance in the utility function, and the production plan affects utility only indirectly through its effect on profit. Thus, the utility function ranks production plans and their implied subjective distributions of profit by the first moment of the distribution, expected profit. However, if there are distress costs and managers trade profit for reduced risk, the production plan will also have marginal significance in the utility function. In this case, the utility function's ranking of production plans will depend, not just on the first moment, but also on higher moments of the implied, subjective distributions of profit.

We condition the managerial utility function on asset or output quality, and use both ex ante and ex post proxies of output quality. Our ex ante measures are the risk premia on assets, given by the vector of asset returns, $\boldsymbol{p}$, relative to the risk-free rate, $r$, and our ex post measure is the amount of nonperforming loans, $n$. Hence, the complete utility function is denoted by $U(\pi, \boldsymbol{y}, \boldsymbol{x}, k, \boldsymbol{p}, r, n)$. Given asset quality, the utility maximizing production plan is the bank's choice of assets, liabilities, equity capital, labor, and physical capital and represents the bank's optimal levered portfolio of information-intensive assets. ${ }^{10}$

\section{B. Choosing the Most Preferred Production Plan}

We assume that managers maximize their utility by choosing profit and inputs, conditional on output quantities, output quality, and financial capital, and subject to the constraints imposed by the income statement and the production technology:

$$
\begin{array}{ll}
\max _{\pi, \boldsymbol{x}} & U(\pi, \boldsymbol{x} ; \boldsymbol{y}, \boldsymbol{p}, r, n, k) \\
& \\
\text { s.t. } & \boldsymbol{p} \cdot \boldsymbol{y}+m-\boldsymbol{w} \cdot \boldsymbol{x}-p_{\pi} \pi=0 \\
& T(\boldsymbol{x} ; \boldsymbol{y}, k) \leq 0,
\end{array}
$$

where $m$ is income from sources other than the output vector $\boldsymbol{y}, \boldsymbol{w}$ is a vector of input prices, $p_{\pi}$ is the price of a real dollar of after-tax profit, $\pi$, in nominal, before-tax dollars. Letting $t$ be the tax rate on profit, we can write

\footnotetext{
${ }^{10}$ This formulation of the bank's production problem is consistent with portfolio-based models of banking. See Santomero (1984) for a discussion of these models.
} 


$$
p_{\pi}=1 /(1-t)
$$

Thus, $p_{\pi} \pi$ is before-tax, nominal profit. The solution to the problem defined by (1) through (3) is the manager's most preferred production plan, which is given by the most preferred input demand functions, $\boldsymbol{x}(\boldsymbol{y}, n, \boldsymbol{v}, m, k)$, and the manager's most preferred profit function, $\pi(\boldsymbol{y}, n, \boldsymbol{v}, m, k)$, where $\boldsymbol{v}=\left(\boldsymbol{w}, \boldsymbol{p}, r, p_{\pi}\right)$.

Three characteristics of the profit function make it distinctive. First, it is not necessarily maximum profit. Second, the input demand functions that underlie the profit function contain unusual arguments: fixed revenues (or, equivalently, fixed costs), $m$, and the tax rate on profit, embedded in $p_{\pi}$. These arguments affect the level of profit but not the values of inputs and outputs at which profit is maximized. Hence, they do not influence the input demands of the profit-maximizing (risk-neutral) firm. Yet, when managers trade profit for reduced risk, their production decisions are influenced by these variables. Accordingly, these variables can serve as a test of whether managers trade return for reduced risk. They also demonstrate the inadequacy of simply adding risk measures to the profit maximization and cost minimization problems. (See Hughes, Lang, Mester, and Moon (1996) for further details.) Finally, the profit function is conditioned on the level of equity capital, so it can be divided by equity capital to convert profit into a rate of return on equity.

\section{Specifying the Most Preferred Production Plan}

Just as a consumer's preferences for goods can be represented by a utility function, our approach describes bank management's preferences for production plans and profit in terms of a managerial utility function. And, just as the consumer chooses the most preferred, affordable bundle of goods, our approach characterizes the bank's management as choosing its most preferred, feasible production plan, where feasibility is determined by the bank's technology and its income statement. To obtain functional forms for the bank's most preferred or, equivalently, utility-maximizing demand functions for inputs and profit, we borrow the Almost Ideal (AI) Demand System from consumer theory and adapt it to represent managerial preferences. Although we have described managerial preferences by the utility function, the AI System employs the expenditure function, which is the dual characterization of preferences (just as the cost function is the dual characterization of technology). The managerial expenditure function is defined as the minimum expenditure on the "goods," profit $\pi$ and inputs $\boldsymbol{x}$, needed to obtain some given level of utility $U^{0}$, conditional on output quantities, output quality, and financial capital: 


$$
{ }_{\pi, \boldsymbol{x}}^{m n} \boldsymbol{w} \cdot \boldsymbol{x}+p_{\pi} \pi
$$

$$
\begin{array}{ll}
\text { s.t. } & U^{0}-U(\boldsymbol{\pi}, \boldsymbol{x} ; \boldsymbol{y}, \boldsymbol{p}, r, n, k)=0 \\
& T(\boldsymbol{x} ; \boldsymbol{y}, k) \leq 0
\end{array}
$$

The solution to (5) through (7) yields the constant-utility demand functions, $\boldsymbol{x}^{u}\left(\boldsymbol{y}, n, v, k, U^{0}\right)$ and $\pi^{u}\left(\boldsymbol{y}, n, v, k, U^{0}\right)$. Substituting these demand functions into (5) gives the expenditure function $E\left(\boldsymbol{y}, n, \boldsymbol{v}, k, U^{0}\right)$. The indirect utility function, $V(\boldsymbol{y}, n, \boldsymbol{v}, m, k)$, is obtained by inverting the expenditure function. Since the expenditure minimization problem (5)-(7) is dual to the utility maximization problem (1)-(3), the maximum utility from the expenditure $(\boldsymbol{p} \cdot \boldsymbol{y}+m)$ is $U^{*}$ while the minimum expenditure needed to achieve $U^{0}=U^{*}$ is $(\boldsymbol{p} \cdot \boldsymbol{y}+m)$. Consequently, $E\left(\boldsymbol{y}, n, \boldsymbol{v}, k, U^{0}\right)=(\boldsymbol{p} \cdot \boldsymbol{y}+m)$.

When the Almost Ideal expenditure function is adapted to represent generalized managerial preferences, the following functional form is obtained:

$$
\ln \mathrm{E}(\cdot)=\ln \mathrm{P}+\mathrm{U} \cdot \beta_{0}\left(\prod_{i} \mathrm{y}_{\mathrm{i}}^{\beta_{\mathrm{i}}}\right)\left(\prod_{i} \mathrm{w}_{\mathrm{j}}{ }_{\mathrm{j}}^{v_{j}}\right) \mathrm{p}_{\pi}^{\mu \mathrm{k}^{\kappa}}
$$

where $\tilde{p}=\sum_{i} p_{i}\left[y_{i} / \sum_{j} y_{j}\right]$, a weighted average of $\boldsymbol{p}$, and 


$$
\begin{aligned}
& \ln \mathrm{P}=\alpha_{0}+\alpha_{\mathrm{p}} \ln \tilde{\mathrm{p}}+\sum_{\mathrm{i}} \delta_{\mathrm{i}} \ln \mathrm{y}_{\mathrm{i}}+\sum_{\mathrm{i}} \omega_{\mathrm{j}} \ln \mathrm{w}_{\mathrm{j}} \\
& +\eta_{\pi} \ln \mathrm{p}_{\pi}+\tau \ln \mathrm{r}+\vartheta \ln \mathrm{n}+\rho \ln \mathrm{k}+\frac{1}{2} \alpha_{\mathrm{pp}}(\ln \tilde{\mathrm{p}})^{2} \\
& +\frac{1}{2} \sum_{\mathrm{i}} \sum_{\mathrm{j}} \delta_{\mathrm{ij}} \ln \mathrm{y}_{\mathrm{i}} \ln \mathrm{y}_{\mathrm{j}} \\
& +\frac{1}{2} \sum_{\mathrm{s}} \sum_{\mathrm{t}} \omega_{\mathrm{ij}}^{*} \ln \mathrm{w}_{\mathrm{s}} \ln \mathrm{w}_{\mathrm{t}}+\frac{1}{2} \eta_{\pi \pi}\left(\ln \mathrm{p}_{\pi}\right)^{2} \\
& +\frac{1}{2} \tau_{\mathrm{rr}}(\ln \mathrm{r})^{2}+\frac{1}{2} \vartheta_{\mathrm{nn}}(\ln \mathrm{n})^{2}+\frac{1}{2} \rho_{\mathrm{kk}}(\ln \mathrm{k})^{2} \\
& +\sum_{\mathrm{j}} \theta_{\mathrm{pj}} \ln \tilde{\mathrm{p}} \ln \mathrm{y}_{\mathrm{j}}+\sum_{\mathrm{s}} \phi_{\mathrm{ps}} \ln \tilde{\mathrm{p}} \ln \mathrm{w}_{\mathrm{s}}+\psi_{\mathrm{p} \pi} \ln \tilde{\mathrm{p}} \ln \mathrm{p}_{\pi} \\
& +\psi_{\mathrm{pr}} \ln \tilde{\mathrm{p}} \ln \mathrm{r}+\psi_{\mathrm{pn}} \ln \tilde{\mathrm{p}} \ln \mathrm{n}+\psi_{\mathrm{pk}} \ln \tilde{\mathrm{p}} \ln \mathrm{k}
\end{aligned}
$$

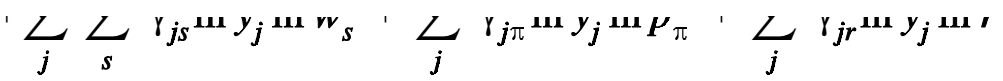

$$
\begin{aligned}
& +\sum_{j} \gamma_{j n} \ln y_{j} \ln n+\sum_{j} \gamma_{j k} \ln y_{j} \ln k \\
& +\frac{1}{2} \sum_{s} \omega_{s \pi}^{*} \ln w_{s} \ln p_{\pi}+\frac{1}{2} \sum_{s} \omega_{\pi s}^{*} \ln p_{\pi} \ln w_{s} \\
& +\sum_{s} \omega_{s r} \ln w_{s} \ln r+\sum_{s} \omega_{s n} \ln w_{s} \ln n+\sum_{s} \omega_{s k} \ln w_{s} \ln k \\
& +\eta_{\pi r} \ln p_{\pi} \ln r+\eta_{\pi n} \ln p_{\pi} \ln n+\eta_{\pi k} \ln p_{\pi} \ln k \\
& +\tau_{r n} \ln r \ln n+\tau_{r k} \ln r \ln k+\vartheta_{n k} \ln n \ln k
\end{aligned}
$$

Inverting the expenditure function gives the indirect utility function:

$$
V(\cdot)=\frac{\ln (\boldsymbol{p} \cdot \boldsymbol{y}+m)-\ln P}{\beta_{0}\left(\prod_{i}^{y_{i}^{\beta_{i}}}\right)\left(\prod_{j} w_{i}^{v_{j}}\right) p_{\pi}^{\mu} k^{\kappa}}
$$

Applying Shephard's lemma to the expenditure function (8) and substituting the indirect utility function (10) into the resulting share equations yields the utility-maximizing, most preferred 
input and profit share equations:

(11)

$$
\begin{aligned}
& \frac{\partial \ln \mathrm{E}}{\partial \ln \mathrm{w}_{\mathrm{i}}}=\frac{\mathrm{w}_{\mathrm{i}} \mathrm{x}_{\mathrm{i}}}{\mathbf{p} \cdot \mathbf{y}+\mathrm{m}}=\frac{\partial \ln \mathrm{P}}{\partial \ln \mathrm{w}_{\mathrm{i}}}+v_{i}[\ln (\mathbf{p} \cdot \mathbf{y}+\mathrm{m})-\ln \mathrm{P}] \\
& =\omega_{\mathrm{i}}+\sum_{\mathrm{s}} \omega_{\mathrm{si}} \ln \mathrm{w}_{\mathrm{s}}+\phi_{\mathrm{pi}} \ln \tilde{\mathrm{p}}+\sum_{\mathrm{j}} \gamma_{\mathrm{ji}} \ln \mathrm{y}_{\mathrm{j}}+\omega_{\pi \mathrm{i}} \ln \mathrm{p}_{\pi} \\
& +\omega_{\mathrm{ir}} \ln \mathrm{r}+\omega_{\mathrm{in}} \ln \mathrm{n}+\omega_{\mathrm{ik}} \ln \mathrm{k} \\
& +v_{\mathrm{i}}[\ln (\mathbf{p} \cdot \mathbf{y}+\mathrm{m})-\ln \mathrm{P}]
\end{aligned}
$$

$$
\begin{aligned}
& \frac{\partial \ln \mathrm{E}}{\partial \ln \mathrm{p}_{\pi}}=\frac{\mathrm{p}_{\pi} \pi}{\mathbf{p} \cdot \mathbf{y}+\mathrm{m}}=\frac{\partial \ln \mathrm{P}}{\partial \ln \mathrm{p}_{\pi}}+\mu[\ln (\mathbf{p} \cdot \mathbf{y}+\mathrm{m})-\ln \mathrm{P}] \\
& =\eta_{\pi}+\eta_{\pi \pi} \ln \mathrm{p}_{\pi}+\Psi_{\mathrm{p} \pi} \ln \tilde{\mathrm{p}}+\sum_{\mathrm{j}} \gamma_{\mathrm{j} \pi} \ln \mathrm{y}_{\mathrm{j}}+\sum_{\mathrm{s}} \omega_{\mathrm{s} \pi} \ln \mathrm{w}_{\mathrm{s}} \\
& \quad+\eta_{\pi \mathrm{r}} \ln \mathrm{r}+\eta_{\pi \mathrm{n}} \ln \mathrm{n}+\eta_{\pi \mathrm{k}} \ln \mathrm{k} \\
& \quad+\mu[\ln (\mathbf{p} \cdot \mathbf{y}+\mathrm{m})-\ln \mathrm{P}] .
\end{aligned}
$$

The conditions on parameter values that are implied by symmetry, homogeneity, and adding up are outlined in Hughes, Lang, Mester, and Moon (1996). Further parameter restrictions are obtained by adding a first-order condition for the most preferred level of equity capital:

$$
\begin{aligned}
\rho+\rho_{k k} \ln k+ & \psi_{p k} \ln \tilde{p}+\sum_{j} \gamma_{j k} \ln y_{j}+\sum_{s} \omega_{s k} \ln w_{s}+\eta_{\pi k} \ln p_{\pi}+\tau_{r k} \ln r \\
& +\vartheta_{n k} \ln n+\kappa[\ln (\boldsymbol{p} \cdot \boldsymbol{y}+m)-\ln P]=0 .
\end{aligned}
$$

which is derived by maximizing the Lagrangean function from the utility maximization problem (1)-(3) with respect to $k$. 


\section{Estimating the Most Preferred Production Plan}

We use nonlinear two-stage least squares, which is a generalized method of moments, to estimate a demand system consisting of the input share equations (11), the profit share equation (12), and the first-order condition for equity capital (13). Because managers rank production plans based on their subjective assessments of future economic conditions and because these assessments and, hence, preferences are likely to change over time, we estimate this demand system using cross-section data. Since the risk-free rate $r$ does not vary in a cross-section, it is omitted, and the homogeneity conditions are used to recover its associated coefficients.

We estimate the system for a sample of 356 national banks that range in asset size from $\$ 83.6$ million to $\$ 120$ billion. The sample includes all national banks that operate domestic and foreign offices plus all other national banks with at least $\$ 300$ million in assets. We exclude special purpose banks. Balance sheet and income statement data are obtained from year-end 1993 and 1994 Consolidated Reports of Condition and Income. Asset and liability variables are the averages of the 1993 and 1994 year-end values, while flow variables are simply the 1994 year-end values. Compared with the late 1980s and early 1990s, 1994 was relatively stable, and the large majority of banks met regulatory capital standards. Although bank managers in 1994 knew that choosing a high risk production plan increased the probability of regulatory actions and financial distress, few banks in 1994 were operating under regulatory constraints that prevented them from choosing their most preferred production plans. The data are summarized in Table 1. The parameter estimates for the structural model are found in Table 2.

We define five outputs: $y_{1}$ is real estate loans; $y_{2}$ is commercial and industrial loans, agricultural loans, and lease financing; $y_{3}$ is individual loans; $y_{4}$ is other loans; and $y_{5}$ is cash and securities. We compute the output prices by dividing the income recorded for accruing assets by the stock of accruing assets. Inputs are divided into six categories: equity capital, $k$, is the sum of equity, subordinated notes, and loan-loss reserves; $x_{1}$ is the quantity of labor, the number of full-time equivalent employees; $x_{2}$ is quantity of physical capital, measured by the dollar amount of fixed premises and assets; $x_{3}$ is insured deposits; $x_{4}$ is other borrowed money; and $x_{5}$ is uninsured deposits and foreign deposits. The average salary of labor, $w_{1}$, is the total labor expense divided by the number of full-time equivalent employees, $x_{1}$. The price of physical capital, $w_{2}$, is measured by the ratio of occupancy expenses to fixed premises and assets $x_{2}$. The average interest rates, $w_{3}, w_{4}, w_{5}$, are the ratios of the interest expense for each funding source to the amount of $x_{3}, \mathrm{x}_{4}$, and $x_{5}$ respectively.

Nonperforming loans, $n$, is the amount of loans past due 90 days or more plus nonaccruing loans. Non-asset-based income, $m$, is measured by total noninterest income so that 
each bank's total revenue, $\boldsymbol{p} \cdot \boldsymbol{y}+m$, equals interest plus noninterest income. ${ }^{11}$ Federal and state tax rates are used to calculate $p_{\pi}$. The state tax rates were obtained from The Book of the States, published by the Council of State Governments, and from Significant Aspects of Fiscal Federalism, published by the U.S. Advisory Commission on Intergovernmental Relations.

\section{E. Deriving Expected Return and Risk}

The fitted values from (12) are each bank's predicted or expected profit as a share are of its total revenue. Since these predicted profit shares are conditioned on the bank's level of equity capital, they can be converted into predictions, or expectations, of the return on equity simply by multiplying by total revenue and dividing by equity capital:

$$
E R=s_{\pi}(\beta) \cdot[(\boldsymbol{p} \cdot \boldsymbol{y}+m) / k]
$$

where $s_{\pi}(\beta)$ denotes the fitted profit shares and $\beta$ denotes the estimated parameters in equation (12). ER is a proxy for the bank's prediction of its own return on equity, and this prediction is a function of the its size and asset mix, its average return on assets, its cost of financial and nonfinancial inputs, the amount of nonperforming loans, its marginal tax rate on profit, and so on. The amount of confidence the bank has about this prediction is an indication of the amount of risk inherent in its most preferred production plan. A bank that chooses an ex ante, high-risk production plan will have less confidence in its prediction of earnings than a bank that chooses an ex ante low-risk production plan. We use a measure of the degree of uncertainty of the predicted return, the standard error of the prediction from (12), as a proxy for the bank's confidence in predicting its return on equity:

$$
R K=\left[\hat{\boldsymbol{X}} \operatorname{vâr}(\boldsymbol{\beta}) \hat{\boldsymbol{X}}^{\prime}\right]^{1 / 2} \cdot[(\boldsymbol{p} \cdot \boldsymbol{y}+\boldsymbol{m}) / k]
$$

where the expression $\left[\hat{\boldsymbol{X}} \operatorname{var}(\boldsymbol{\beta}) \hat{\boldsymbol{X}}^{\prime}\right]$ is the estimated asymptotic variance of the forecast $s_{\pi}(\beta)$, and $\hat{\boldsymbol{X}}=\partial s_{\pi}(\beta) / \partial \beta$. This measure of return risk is a function of the bank's size and asset composition, its average return on assets, its costs of financial and nonfinancial inputs, its marginal tax rate on profits, its amount of nonperforming loans, and so on. Hughes and Moon

\footnotetext{
${ }^{11}$ Note that our measure of non-asset-based income, $m$, is a proxy for revenues that are unrelated to bank output, defined by the vector $\mathbf{y}$. At most banks, $m$ will be related to some extent to non-asset-based outputs that are not accounted for in our vector of outputs, whose definition reflects the role of banks as pure financial intermediaries.
} 
(1995) and Hughes, Lang, Mester, and Moon (1998) show that expected profit $(E R \cdot k)$ and profit risk $(R K \cdot k)$ explain 96 percent of the variation in the market value of the publicly traded banks in their sample. In addition, the coefficient on profit is significantly positive while the coefficient on profit risk is significantly negative. Hence, these measures of profitability and risk derived from the most preferred model of production are priced by capital markets.

We do not impose homoskedasticity on the error terms in our estimation. Our nonlinear two-stage least squares estimation technique uses orthogonality conditions between instrumental variables and the error terms of our structural equation system. The resulting variancecovariance matrix $\operatorname{vâr}(\beta)$ is not based on a constant error variance across all banks, but instead captures how the error variance differs with different types of production plans. This estimation procedure allows the data to reveal the pattern of heteroskedasticity without imposing structure, which is consistent with our general approach of letting banks' choices of production plans reveal the amount of risk they prefer. Thus, for each bank in our sample, (14) provides the first moment of the distribution of the return on equity while (15) constitutes a proxy for the second moment. Note that $E R$ and $R K$ are ex ante measures of return and risk.

Figure 2 is a scatter diagram of expected return and return risk for the 356 banks in our sample. The diagram is stated in terms of $E R^{\prime}$ and $R K^{\prime}$, which are equal to the estimated values of $E R$ and $R K$ after rescaling by their respective sample standard deviations. We perform the remainder of our analysis using the rescaled values, $E R^{\prime}$ and $R K^{\prime}$, which facilitates subsequent regression analyses without altering the empirical relationships among the variables.

\section{Estimating Efficiency and the Best-Practice Frontier}

Each pair $(E R, R K)$ represents the trade-off that an individual bank has made between expected return and risk. Because not all banks are equally proficient at generating return and controlling risk, the risk-return frontier of a relatively efficient bank will lie above the risk-return frontier of a relatively inefficient bank. This suggests that inefficient banks could potentially increase their expected return without taking more risk or, equivalently, reduce their risk without sacrificing return. By enhancing their risk-return profiles in this way, inefficient banks can move to higher risk-return frontiers, the highest of which is the best-practice frontier. Because the best-practice frontier may contain portions of the frontiers of many individual banks, it is the envelope of the frontiers of efficient banks or, more precisely, it is the envelope of their most preferred risk-return combinations.

Figure 3 shows a stylized version of the envelope frontier. The bank positioned at point A is inefficient. Although its most preferred combination of return and risk is a point on its own 
frontier, its own frontier lies inside the best-practice envelope. The degree to which point $\mathrm{A}$ is inefficient can be measured by its distance from the frontier. Holding the level of risk constant at point A, we employ the difference between expected return at $\mathrm{A}$ and maximum return at $\mathrm{B}$ to gauge the inefficiency of point A. This shortfall in expected return, given a bank's choice of risk, can be readily estimated using econometric frontier techniques.

\section{A. Estimating a Stochastic Risk-Return Frontier}

Using techniques developed by Jondrow, Lovell, Materov, and Schmidt (1982), we estimate the best-practice risk-return frontier as the upper envelope of expected returns, given their associated levels of risk. Banks located below the estimated frontier are inefficient and their vertical distance from the frontier is their degree of inefficiency. We specify the frontier as

$$
E R=a+b R K+c R K^{2}+v-u
$$

where

$$
\begin{aligned}
u_{\mathrm{i}} \geq 0 & \sim \operatorname{IIDN}\left(0, \sigma_{\mathrm{u}}^{2}\right) \text { truncated at } 0 \\
v_{\mathrm{i}} & \sim \operatorname{IID~} \mathrm{N}\left(0, \sigma_{\mathrm{v}}{ }^{2}\right) .
\end{aligned}
$$

The error term consists of two components: $v$ is a normally distributed, two-sided, term that allows for unmeasured randomness in the data generation process, and $u$ is a one-sided, normally distributed, nonnegative term that measures vertical return inefficiency, the failure to achieve maximum return given the level of risk. After rescaling both $E R$ and $R K$ by their respective sample standard deviations, we estimate (16) using maximum likelihood techniques. The resulting envelope frontier is shown in Figure 4, and is given by the equation,

$$
E R^{\prime}=\begin{aligned}
3.2204+0.2548 * R K^{\prime}+ & 0.0672 *\left(R K^{\prime}\right)^{2} \\
& (0.2028)(0.1315)
\end{aligned}
$$

where the standard errors of the coefficient estimates appear in parentheses. Note that some of the banks are located above the frontier in Figure 4. This apparent superefficiency occurs when the random noise term, $v_{\mathrm{i}}$, is positive and larger than the inefficiency term, $u_{\mathrm{i}}$. Subtracting $v_{\mathrm{i}}$ from $E R$ yields the "noise-adjusted" expected return, $E R-v_{\mathrm{i}}$, which lies below the frontier.

The shape of the frontier in Figure 4 has two striking features. First, its positive slope suggests that banks are not pure profit maximizers, but rather are trading return for reduced risk. To confirm this appearance, we applied a Wald test to the 31 conditions implied by profit 
maximization described in Appendix A. The value of the test statistic was 204.07 with 29 degrees of freedom (two of the restrictions are made redundant by the adding-up conditions). Thus, the hypothesis that these restrictions hold can be strongly rejected, i.e., the banks' behavior is not consistent with profit maximization. Second, the frontier is convex in risk. This convexity implies that there are combinations (e.g., mergers) of banks that would result in a better risk-return trade-off, that is to say, a concave frontier. Hughes and Moon (1995) hypothesize that because state and federal laws have historically restricted the geographic expansion of U.S. banks, individual banks have not been able to form mergers that would exploit these risk-return tradeoffs. Hughes, Lang, Mester, and Moon (1996) provide evidence in support of this hypothesis. They estimate a production-based, expected return-risk frontier that is identical to the one in Figure 4 with one exception: they estimate it for a 1994 sample of large U.S. bank holding companies, i.e., firms that in many cases could legally circumvent geographic banking restrictions by organizing the geographically dispersed banks from our data set (along with other assets) into separate affiliates rather than merging them together. Strikingly, they obtain a frontier that is concave in risk, which suggests that the parent firms of the banks in our sample have in fact captured the improved risk-return tradeoffs that appear to be unexploited in Figure 4. Nevertheless, we must employ the bank-level frontier to obtain efficiency scores since the CAMEL ratings are assigned to individual banks rather than to holding companies.

\section{CAMEL Ratings and Banks' Risk-Return Trade-offs}

The last stage of our analysis focuses on the key questions: Do regulators assign better CAMEL ratings to banks that trade expected return for a reduced risk of financial distress, and do they treat the risk-taking of inefficient banks differently than the risk-taking of efficient banks? To investigate these questions, we estimate an ordered logit model that specifies each bank's composite CAMEL rating as a function of its risk-return trade-off.

The dependent variable in the ordered logit model is the most recent CAMEL rating for each national bank as of year-end 1994. For our sample of 356 national banks, 39.6\% were 1rated; $58.1 \%$ were 2 -rated; $2.3 \%$ were 3 -rated; and none were 4 -rated or 5-rated. This distribution of CAMEL ratings suggests that national banks were substantially more safe and sound in 1994 than just a few years earlier, when nearly ten percent of national banks had CAMEL ratings of 4 or 5 (DeYoung, 1998). However, note that our sample excludes domestic national banks with less than $\$ 300$ million in assets, and those banks comprised the large majority of the 3,078 national banks operating as of year-end 1994.

On the right-hand side of the model, we include each bank's risk, its frontier expected 
return, its inefficiency, and its asset size. Risk and frontier expected return correspond to the coordinates of point B (the estimated values $R K^{\prime}$ and $E R^{\prime}$ ) in Figure 3, while inefficiency (the estimated value of $u_{\mathrm{i}}$ ) is the distance $\mathrm{AB}$ after adjusting for statistical noise. This specification allows us to test for the regulator's evaluation of banks' risk-return choices independent from its evaluation of bank inefficiency. We include bank asset size as a regressor since DeYoung (1998) found that exam ratings were significantly and positively related to bank size.

We estimate these regressions three times: for the entire sample of 356 banks, for the more efficient half of the sample (values of $u_{\mathrm{i}}$ below the median), and, finally, for the less efficient half of the sample. The results of these three sets of regressions are reported in Table 3. The contrasts among the full sample of 356 banks and the more and less efficient groups are striking. For the more efficient banks, CAMEL ratings appear to be unrelated to their risk-return trade-offs. In contrast, the risk-return trade-offs do matter to the regulator for the less efficient banks and for the full sample. This first impression suggests that bank supervisors are influenced not only by the banks' risk-return choices, but also by how efficiently banks make this trade-off.

\section{A. The Entire Sample}

The results for the full sample of 356 banks are displayed in the first column of Table 3. Since examiners assign numerically low CAMEL ratings to banks that they judge to be safe and sound, we would expect exam ratings to vary positively with risk and inefficiency and negatively with expected return. The coefficient on inefficiency is positive and significant, evidence that examiners penalize banks for operating below the best-practice frontier. CAMEL ratings also vary significantly and positively with risk, and significantly and negatively with expected return. The coefficient on asset size is positive and significant, evidence that national bank examiners set higher standards for larger banks.

A more intriguing question asks how the CAMEL rating responds when banks increase both risk and return along the efficient frontier. If we take the total differential of the estimated CAMEL rating equation, reported in the first column of Table 3, with respect to return and risk, holding asset size constant and the degree of inefficiency constant and equal to zero along the frontier, we obtain

$$
\mathrm{d}(\text { CAMEL rating })=1.8962 \mathrm{~d}\left(R K^{\prime}\right)-3.0461 \mathrm{~d}\left(E R^{\prime}\right) .
$$

Setting (20) equal to zero and rearranging, we obtain the slope of the iso-CAMEL-rating contours for efficient banks, holding asset size constant: 
The iso-CAMEL-rating contours are linear and have positive slopes that are greater than the slope of the risk-return frontier, $\mathrm{d} E R^{\prime} / \mathrm{d} R K^{\prime}$ from (19), for 85 percent of the banks in our sample. In these cases, as a bank moves along the risk-return frontier to a higher return and higher risk position, it also moves to a less favorable iso-CAMEL-rating contour. (That is, the bank moves to an iso-CAMEL-rating contour that lies further to the right -- a contour that is identified with a higher level of risk for any given level of expected return, and thus with a worse exam score.) Consequently, examiners penalize most banks that take extra risk for extra return by assigning them a worse CAMEL rating. The poorer rating implies that these banks are relatively less safe and sound and, thus, are more likely to experience remedial covenant enforcement.

\section{B. Subsamples of Efficient and Inefficient Banks}

The second and third columns of Table 3 report the results from estimating the ordered logit model separately for the 178 most efficient (henceforth the "efficient") and the 178 least efficient (henceforth the "inefficient") banks. The results suggest a clear dichotomy in the way that examiners evaluate these two sets of banks. The risk-return trade-offs (i.e., the coefficients on $R K^{\prime}$ and $E R^{\prime}$ ) made by the efficient banks have no statistically significant effect on their CAMEL ratings. Examiners appear to be neutral toward the risk-return choices made by these banks, which operate relatively close to the frontier and efficiently manage risk and generate returns. In contrast, the trade-offs made by the inefficient banks do matter to bank supervisors. These banks are relatively inefficient at trading risk for return -- that is, they operate along an inefficient risk-return frontier -- and examiners appear to penalize them for taking greater risk for extra return. Hence, when relatively inefficient banks take extra risk for extra expected return, they are more likely to experience remedial covenant enforcement. This suggests that regulators impose greater discipline and higher distress costs on inefficient banks than on efficient banks.

Examiners also appear to treat asset size differently for efficient and inefficient banks. The positive, significant coefficient on total assets for inefficient banks suggests that size counts against the bank if it is inefficient. In contrast, the results for the efficient-bank subsample indicates that examiners are neutral with respect to asset size for banks that demonstrate an ability to manage risk and produce return efficiently. Furthermore, the degree of inefficiency is the only significant explanatory variable for the efficient banks; that is, the higher the degree of 
inefficiency, the worse the exam rating. ${ }^{12}$

Regulatory covenant monitoring therefore appears to provide all banks -- relatively efficient and relatively inefficient alike -- with an incentive to improve the efficiency with which they manage risk. But, this treatment is asymmetric. When banks choose higher-risk production plans, relatively inefficient banks are more likely to experience remedial covenant enforcement than relatively efficient banks, and the larger the inefficient bank, the greater the likelihood of regulatory intervention. This distinction between the supervisory treatment of more and less efficient banks suggests that, in a more competitive and deregulated environment, opportunities for risk-taking will not be encouraged equally for all banks. However, even within this dichotomy, supervisors provide an incentive for all banks to become more efficient.

\section{The CAMEL Component Ratings}

In Table 4, we substitute the five individual CAMEL components into the left-hand-side of the full-sample ordered logit model. All five of these regressions suggest that examiners hold large banks to significantly higher standards than small banks. However, the coefficients on expected return, risk, and inefficiency vary across the five regressions in a manner that reflects the unique information contained in the $\mathrm{C}, \mathrm{A}, \mathrm{M}, \mathrm{E}$, and L ratings.

The $\mathrm{C}$ (capital adequacy) and A (asset quality) regressions produce results quite similar to the composite CAMEL regression. The coefficient on risk is positive and significant in both regressions, indicating that examiners prefer increased capital for high-risk banks and associate high amounts of risk with low asset quality. The coefficient on return is negative and significant in both regressions, indicating that examiners associate higher amounts of return with higher asset quality and are more likely to find capital levels at higher-return banks to be adequate. The coefficient on assets is larger in the C-rating regressions than in the other four regressions, perhaps because large bank failures are more disruptive than small bank failures and can lead to systemic problems. Although the significantly negative coefficient on inefficiency in the C-rating regression at first seems unintuitive, it probably reflects the relationship between financial leverage and return on equity. Banks with low amounts of leverage will have better

\footnotetext{
${ }^{12}$ To test the robustness of these subsample results, we estimated an additional logit model for the entire sample of 356 banks. In this model, we replaced the continuous Inefficiency variable with a binary variable that distinguished between banks in the efficient and inefficient subsamples, and the variables Assets, Risk, and Frontier Expected Return entered the model both linearly and interacted with the binary variable. The results of this model (which are available from the authors upon request) were qualitatively similar in sign and significance to the results of the Table 3 subsample regressions.
} 
C-ratings, but they will also be inefficient (by our measure) because they have reduced their expected return on equity without any compensating reduction in risk.

The M-rating (management quality) and E-rating (earnings quality) measure the two performance areas most directly related to inefficient operations, and the coefficient on inefficiency is positive and significant in both of these regressions. High quality managers can presumably run a bank more efficiently than can low quality managers, and an efficiently run bank will naturally generate larger expected earnings. Due to strong definitional similarities, the E-rating is significantly related in the expected direction to both expected return and inefficiency.

Neither the risk-return trade-off nor the degree of inefficiency has a significant impact on the L-rating (liquidity). In fact, asset size is the only significant coefficient, suggesting that examiners consider illiquidity at larger banks more disruptive to the payments system than illiquidity at smaller banks.

\section{Conclusions}

In an era of deregulation that seeks to increase banks' competition and to improve their efficiency, regulation has been linked to the risk that banks take to address the increased incentives to take risk that are created by reduced charter values and mispriced safety nets. In addition, banks whose risk-taking leads to episodes of financial distress experience costly regulatory strictures that generally reduce the risk-taking incentives for all banks. Using CAMEL ratings that indicate the likelihood that such strictures will be imposed, we have asked if commercial bank regulators distinguish between a bank's level of risk and its efficiency at risktaking in their ratings of banks. Do bank regulators treat the risk-taking of efficient banks differently than the risk-taking of inefficient banks? Do regulators afford efficient banks more latitude in their investment strategies than inefficient banks? Do regulators create incentives for banks to improve the efficiency of their risk-taking? We have offered evidence that answers, "Yes," to each of these questions.

The evidence seems to indicate that examiners draw a line between efficient banks and inefficient banks. Efficient banks are better at risk-taking, and when they take extra risk to increase their expected return, our results suggest that examiners do not penalize them with worse CAMEL ratings. Apparently, their "best-practice" ability to manage risk enables them to take extra risk without compromising their safety and soundness. Hence, the evidence implies that bank regulators impose lower distress costs on these banks and that the structure of these costs encourages efficiency but does not discourage efficient risk-taking.

For banks with less ability to manage risks or to enhance return, however, CAMEL 
ratings do reflect the risk-return trade-off. Examiners penalize these banks for taking increased risk. In addition, our results suggest that supervisors hold large inefficient banks (i.e., banks whose safety and soundness is most likely to have implications for the stability of the banking system) to higher standards than large efficient banks. Thus, the higher schedule of distress costs imposed on inefficient banks gives them the incentive to become more efficient and to take less risk, and the larger the inefficient bank, the greater these incentives. Thus, our evidence suggests that opportunities for risk-taking created in a more competitive, deregulated banking industry are not encouraged equally for all banks and that this differential treatment of banks encourages all banks to manage risk more efficiently. 


\section{Appendix A}

\section{Testing for Profit Maximization}

When managers maximize profit or, equivalently, minimize cost, the resulting input demands and before-tax profit are not affected by marginal tax rates on profits and by fixed charges and revenues. Using these propositions, Hughes, Lang, Mester, and Moon (1995) derive the parameter values implied by profit maximization and use them to test for managerial behavior consistent with profit maximization. We also apply these tests to our sample of national banks. Since the most preferred profit function is conditioned on the level of equity capital, maximizing profit in this case is equivalent to maximizing the rate of return on equity.

Using the implication of profit maximization that the marginal tax rate on profit will not influence the maximum before-tax level of profit, the coefficients associated with the price of profit, $p_{\pi}$, should all equal zero:

$$
\eta_{\pi}=\eta_{\pi \pi}=\psi_{p \pi}=\gamma_{j \pi}=\omega_{s \pi}=\eta_{\pi n}=\eta_{\pi k}=0 \quad \vee \mathrm{j}, \mathrm{s}
$$

Imposing (P1) on the most preferred production system (11)-(12), the profit share equation (12), becomes

$$
p_{\pi} \pi /(\boldsymbol{p} \cdot \boldsymbol{y}+m)=\mu[\ln (\boldsymbol{p} \cdot \boldsymbol{y}+m)-\ln P] .
$$

Hughes et al. also note that the output price vector, $\mathbf{p}$, summarized by its weighted average price, $\tilde{p}$, cannot affect the profit-maximizing or cost-minimizing solution since the maximization problem is conditioned on the output vector. Hence, all coefficients associated with the average output price must also equal zero:

$$
\alpha_{p}=\alpha_{p p}=\theta_{p j}=\varphi_{p s}=\Psi_{p \pi}=\Psi_{p n}=\Psi_{p k}=0 \vee \mathrm{j}, \mathrm{s}
$$

In addition, fixed revenue or cost, $m$, cannot affect the profit-maximizing or cost-minimizing input demands, $\boldsymbol{x}$ and $k$. Thus, the numerators, $\boldsymbol{w} \cdot \mathbf{x}$, of the input share equations (11) are invariant to $m$ so that the only effect of a variation in $m$ is on profit: $\partial\left(p_{\pi} \pi\right) / \partial m=1$. If the share equations (11)-(12) are differentiated with respect to $\ln m$ and these conditions are imposed, then the following parameter values are obtained: 


$$
\begin{aligned}
& v_{i}=\partial\left(w_{i} x_{i} /(\boldsymbol{p} \cdot \boldsymbol{y}+m)\right) / \partial \ln m=-w_{i} x_{i} /(\boldsymbol{p} \cdot \boldsymbol{y}+m), \\
& \mu_{i}=\partial\left(p_{\pi} \pi /(\boldsymbol{p} \cdot \boldsymbol{y}+m)\right) / \partial \ln m=1-\left(p_{\pi} \pi /(\boldsymbol{p} \cdot \boldsymbol{y}+m)\right),
\end{aligned}
$$

while eliminating the influence of $m$ on capitalization in the first-order condition, (13), requires that

$$
\kappa=0 .
$$

Thus, the implications (P3) consist of (A2)-(A4).

Hughes et al. demonstrate that these conditions (P1)-(P3) reduce the most preferred profit and input revenue-share equations to the standard translog cost and input cost-share equations. Hence, when the parameter values implied by profit maximization or, equivalently, risk neutrality are imposed on the Almost Ideal input and profit share equations, they become equivalent to the standard translog cost function and input cost-share equations. 


\section{References}

Akhavein, J.D., Allen N. Berger, and David Humphrey, "The Effects of Megamergers on Efficiency and Prices: Evidence from the Bank Profit Function," Review of Industrial Organization, 12, 1997, 95-139.

Berger, Allen N., and Sally M. Davies, "The Informational Content of Bank Examinations," Journal of Financial Services Research, forthcoming, 1999.

Berger, Allen N., Sally M. Davies, and Mark J. Flannery, "Comparing Market and Regulatory Assessments of Bank Performance: Who Knows What When?" Federal Reserve Board of Governors FEDS working paper, 1998.

Berger, Allen N., and Loretta J. Mester, "Inside the Black Box: What Explains Differences in Efficiencies of Financial Institutions?” Journal of Banking and Finance, 21, 1997, 895-947.

Black, Fischer, "Bank Funds Management in an Efficient Market," Journal of Financial Economics, 2, 1975, 323-339.

Cargill, Thomas, "CAMEL Ratings and the CD Market," Journal of Financial Services Research, 3, 1989, 347-358.

Cole, Rebel, and Jeffrey Gunther, "Predicting Bank Failures: A Comparison of On- and Off-Site Monitoring Systems," Journal of Financial Services Research, forthcoming 1998.

Dahl, Drew, Gerald Hanweck, and John O'Keefe, "The Influence of Auditors and Examiners on Accounting Discretion in the Banking Industry," unpublished working paper, October 1996.

Deaton, Angus, and John Muellbauer, "An Almost Ideal Demand System," American Economic Review, 70:3, June 1980, 312-326.

Demsetz, Rebecca S., Marc R. Saidenberg, and Philip E. Strahan, "Banks with Something to Lose: The Disciplinary Role of Franchise Value," Federal Reserve Bank of New York, Economic Policy Review, October 1996, 2:2, 1-14.

Dewatripont, Mathias, and Jean Tirole, The Prudential Regulation of Banks, Cambridge: MIT Press, 1994.

DeYoung, Robert, "X-Efficiency and Management Quality in Commercial Banks," Journal of Financial Services Research, 11: 5-22, 1998.

DeYoung, Robert, Mark J. Flannery, William Lang, and Sorin Sorescu, "The Informational Advantage of Specialized Monitors: The Case of Bank Examiners," Federal Reserve Bank of Chicago, Working Paper 98-4, August 1998.

DeYoung, Robert, Iftekhar Hasan, and Bruce Kirchhoff, "The Impact of Out-of-State Entry on the Cost Efficiency of Local Commercial Banks," Journal of Economics and Business 50: 191203, 1998. 
Fama, Eugene, “What's Different About Banks?" Journal of Monetary Economics, 15, 1985, 29-39.

Flannery, Mark J., and Joel Houston, "Market Responses to Federal Examinations of U.S. Bank Holding Companies," Working Paper, University of Florida, March 1994.

Freixas, Xavier, and Jean-Charles Rochet, Microeconomics of Banking, Cambridge: MIT Press, 1997.

Gilbert, R. Alton, "Implications of Annual Examinations for the Bank Insurance Fund," Economic Review, Federal Reserve Bank of St. Louis, Jan./Feb. 1993, 35-52.

Hall, John R., Andrew P. Meyer, and Mark D. Vaughan, "Do Markets and Regulators View Bank Risk Similarly? An Empirical Investigation of Market-Based Risk Measures and Regulators' BOPEC Scores for Bank Holding Companies," Working Paper, February 1997.

Hirschhorn, Eric, "The Informational Content of Bank Examination Ratings," Banking and Economic Review, Federal Deposit Insurance Corporation, July/August, 1987, 6-11.

Hughes, Joseph P., "Hospital Cost Functions: The Case of Revenues Affect Production," Working Paper No. 1990-01, Department of Economics, Rutgers University, November 1989.

Hughes, Joseph P., "The Theory and Estimation of Revenue-Driven Costs: The Case of Higher Education," Department of Economics, Rutgers University, February 1990.

Hughes, Joseph P., William Lang, Loretta J. Mester, and Choon-Geol Moon, "Risk-Taking by U.S. Thrifts: Modeling Risk Indicative, Endogenous Interest Rates," Department of Economics, Rutgers University, 1993.

Hughes, Joseph P., William Lang, Loretta J. Mester, and Choon-Geol Moon, "Recovering Technologies That Account for Generalized Managerial Preferences: An Application to Non-Risk-Neutral Banks," Working Paper No. 95-8/R, Federal Reserve Bank of Philadelphia, September 1995.

Hughes, Joseph P., William Lang, Loretta J. Mester, and Choon-Geol Moon, "Efficient Banking Under Interstate Branching," Journal of Money, Credit, and Banking, 28:4 , Nov. 1996 (Part II), 1045-1071.

Hughes, Joseph P., William Lang, Loretta J. Mester, and Choon-Geol Moon, "The Dollars and Sense of Bank Consolidation," Journal of Banking and Finance, 23, 1999, 291-224.

Hughes, Joseph P., and Loretta J. Mester, "Bank Capitalization and Cost: Evidence of Scale Economies in Risk Management and Signaling," Review of Economics and Statistics, 80, 1998, 314-325.

Hughes, Joseph P., and Choon-Geol Moon, "Measuring Bank Efficiency When Managers Trade Return for Reduced Risk," Working Paper, Department of Economics, Rutgers University, September 1995 (revised September 1997). 
James, Christopher, "Some Evidence on the Uniqueness of Bank Loans," Journal of Financial Economics, 19, 1987, 217-235.

Jondrow, J., C.A.K. Lovell, I.S. Materov, and P. Schmidt, "On the Estimation of Technical Inefficiency in the Stochastic Frontier Production Function Model," Journal of Econometrics, 19, 1982, 233-238.

Kane, Edward J., and Burton G. Malkiel, "Bank Portfolio Allocation, Deposit Variability, and the Availability Doctrine," Quarterly Journal of Economics, 79, 1965, 113-134.

Keeley, Michael C., "Deposit Insurance, Risk, and Market Power in Banking," American Economic Review, 80:5, Dec. 1990, 1183-1200.

Kwan, Simon H., and Robert A. Eisenbeis, "An Analysis of Inefficiencies in Banking: A Stochastic Cost Frontier Approach," Federal Reserve Bank of San Francisco, Economic Review, No. 2, 1996.

Lucas, Deborah J., and Robert L. McDonald, "Bank Financing and Investment Decisions with Asymmetric Information about Loan Quality," RAND Journal of Economics, 23:1, Spring 1992, 86-105.

Marcus, Alan J., "Deregulation and Bank Financial Policy," Journal of Banking and Finance, 8, 1984, 557-565.

Merton, Robert C., "An Analytic Derivation of the Cost of Deposit Insurance Loan Guarantees," Journal of Banking and Finance, 1, 1977, 3-11.

Office of the Comptroller of the Currency, "Uniform Financial Institutions Rating System," Examining Circular 159, Washington, D.C., 1979.

O'Keefe, John, and Drew Dahl, "The Scheduling and Reliability of Bank Examinations: The Effect of FDICIA," paper presented to the Financial Management Association, October 1996.

Santomero, Anthony M., "Modeling the Banking Firm," Journal of Money, Credit, and Banking, 16:4, November 1984, Part 2, 576-602.

Simons, Katerina, and Stephen Cross, "Do Capital Markets Predict Problems in Large Commercial Banks?" New England Economic Review, Federal Reserve Bank of Boston, April/June 1991, 51-56.

Smith, Clifford W., and Rene Stulz, "The Determinants of Firms' Hedging Policies," Journal of Financial and Quantitative Analysis, 20:4, December 1985, 391-405. 


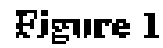

Risk-Return Trade-offs

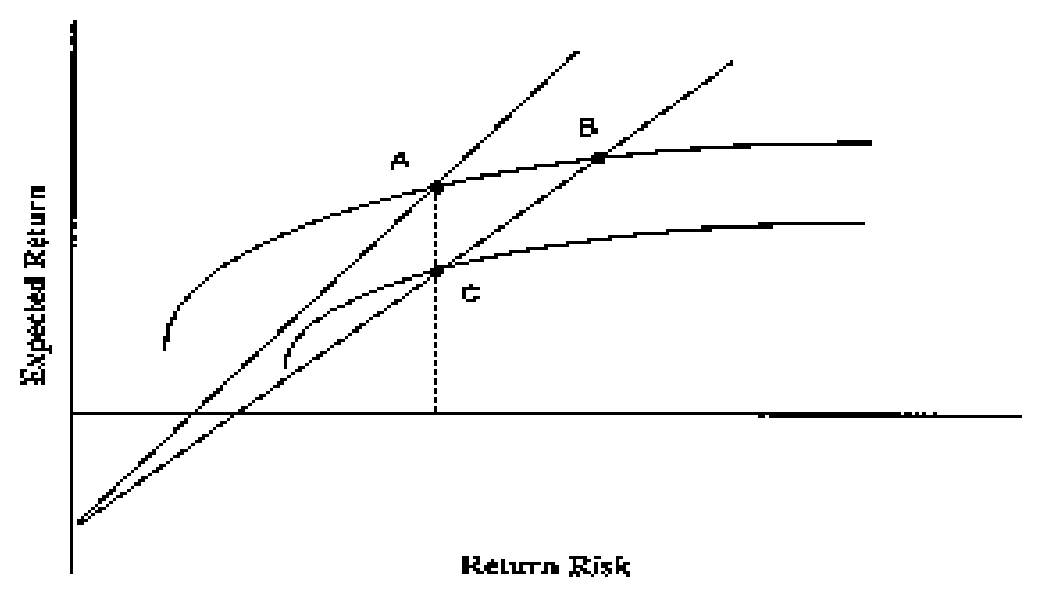

Figure 2

Expected Return and Risk for Sample of 356 National Ean

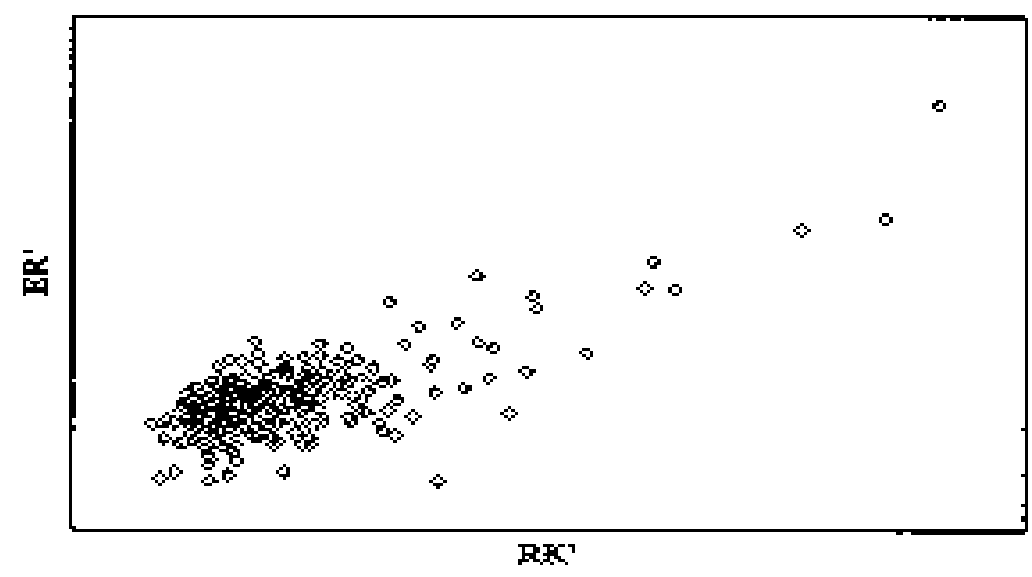


Figure 3

Measurite Efficlctey When Wungers

Trade Rctum Fur Reduced kisk

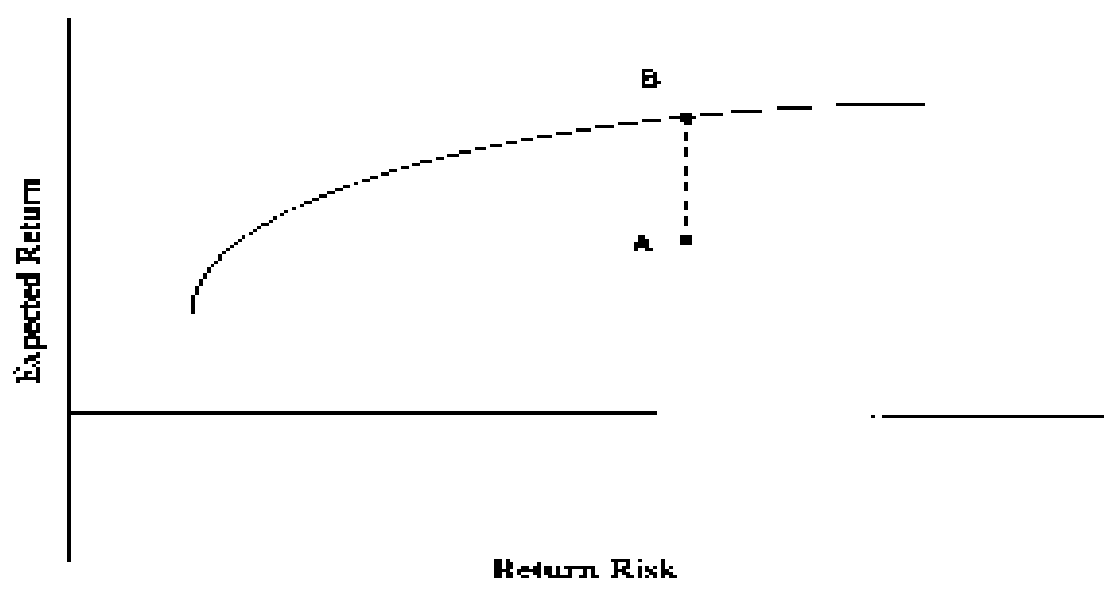

Fipure 4

The Best-Pracllce Sto-hustic Risk-Peturn Frontier

for Sample ur 356 Watinnal thanks

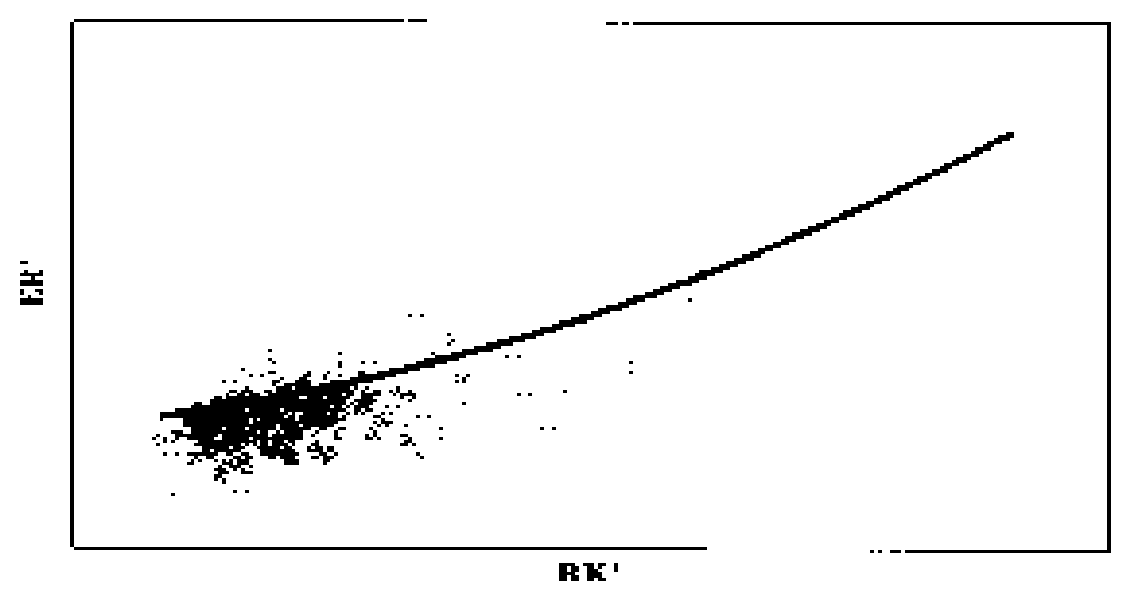


'T'abilu' I

Sั่แ

\begin{tabular}{|c|c|c|c|c|}
\hline $7 a x d a b l$. & Seple Hate & Sed. Der. & HInImin & 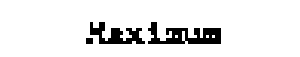 \\
\hline$y 1$ & 1207759.460674 & 3975462.412731 & 57455,000000 & 45654000.000000 \\
\hline & 568712.581461 & & & 4953000.000000 \\
\hline$y^{3}$ & 2.012640 & 508 & & ogo \\
\hline 4 & 292406.606798 & 1520048.654382 & 190,500000 & 900,000400 \\
\hline$y^{5}$ & 1391093 J01966 & $3945076.35455 \mathrm{~J}$ & 22675,500000 & 5031000,000000 \\
\hline pl & 0.081497 & 0.012368 & 27320 & 0.134060 \\
\hline & & 47 & & 0.2 \\
\hline & & & & \\
\hline 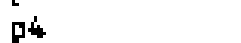 & 0.0 & 025372 & 6060 & 0.189570 \\
\hline p5 & 0.057733 & 0.011903 & & 0,128520 \\
\hline & 0.075503 & & 0.6 & 19102 \\
\hline $\mathbf{L}$ & 35. & & & \\
\hline 2 & & & & 1960 \\
\hline w] & 0.016574 & 0.003961 & 0.505619 & $0.03207 T$ \\
\hline 4 & 0.044695 & $0, B$ & & 9790 \\
\hline & 0.0436 & & & \\
\hline & 1.64 & 0.0 & 1.5 & \\
\hline & 0.1949 & 0.052 & 0.0 & 155759 \\
\hline xhatez & 0.059047 & 0.019 & & 0.129282 \\
\hline sh:x 1 & 0.155195 & 0.050604 & & 1166 \\
\hline & 0.061693 & & & \\
\hline & 0.039714 & 0.035 & 0.003102 & 0.208674 \\
\hline & 0.499348 & 0.079115 & 0.222644 & 0.749910 \\
\hline & 52161.026090 & 67.117232 & 13.300900 & 000.000000 \\
\hline & 504672.141854 & 1706694.610322 & & \\
\hline & & & & 100.000000 \\
\hline & 2985721.070707 & & 1009001 & 120000000.000000 \\
\hline
\end{tabular}

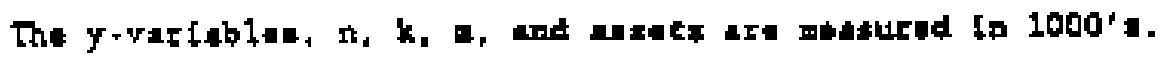




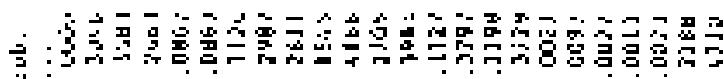

H

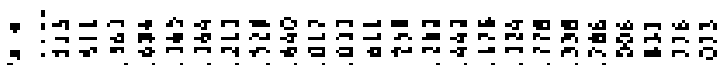

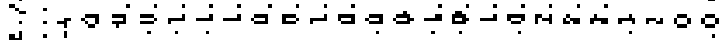

घ.

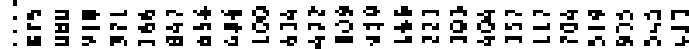

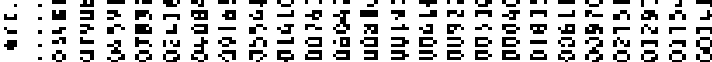

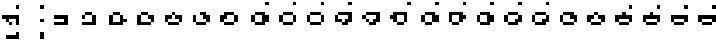
जा

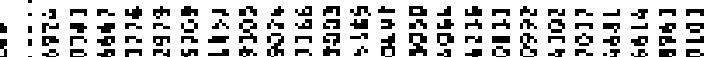

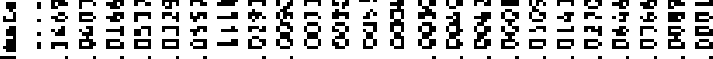

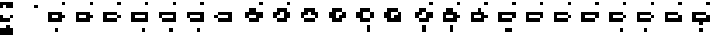

$\vdots$

ت:

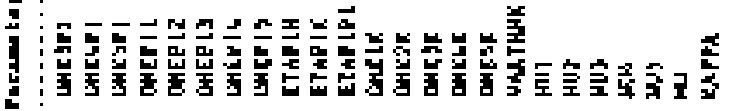

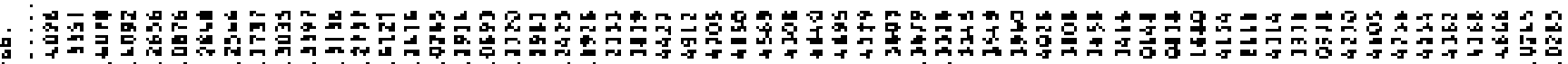

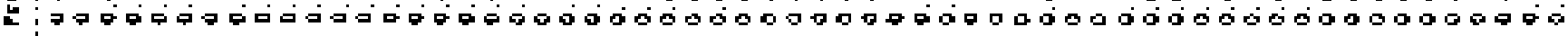

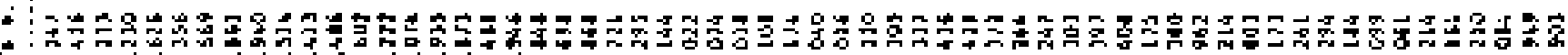

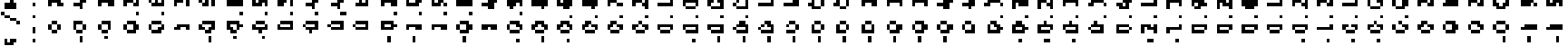
案

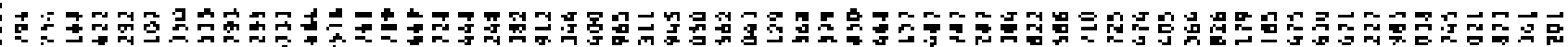

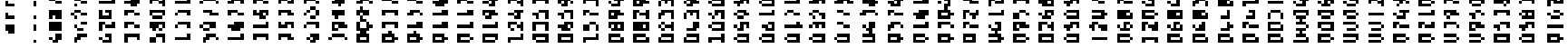

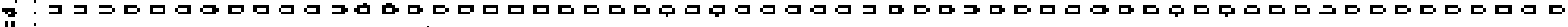

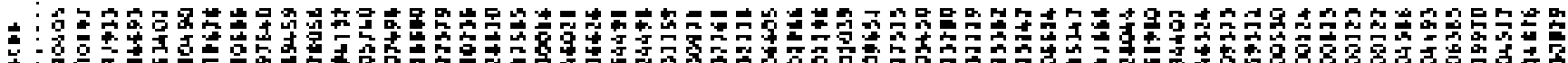

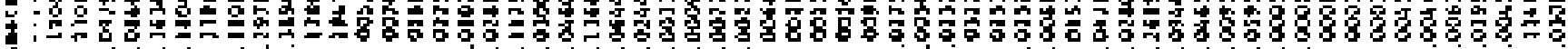

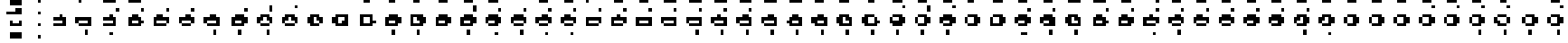

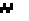

3

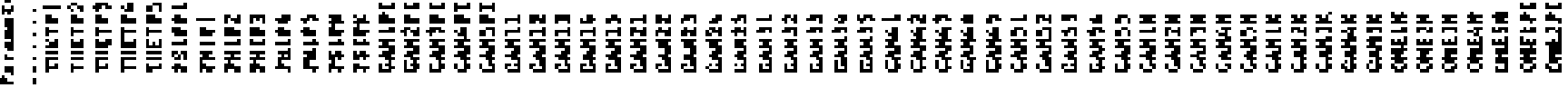

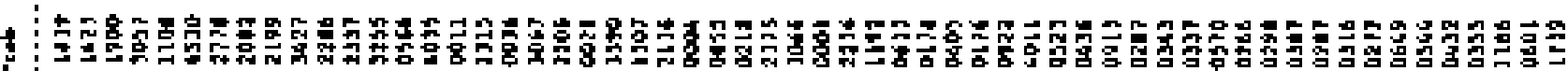

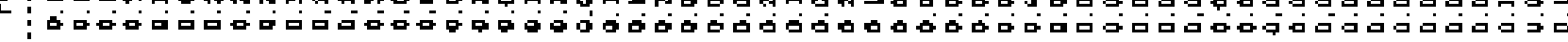

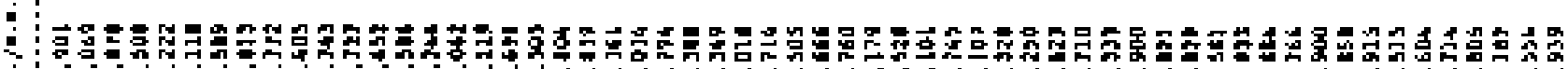

ز

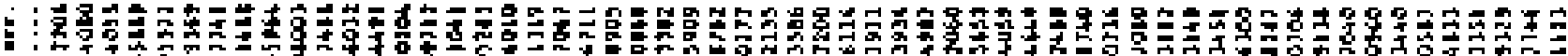

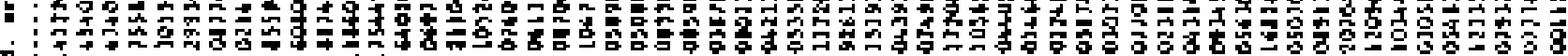

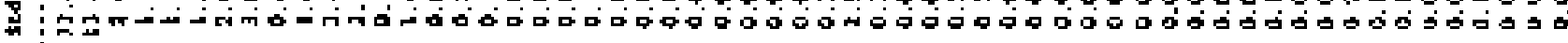

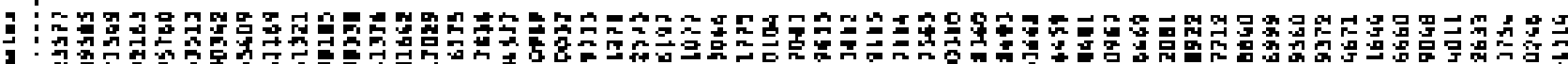

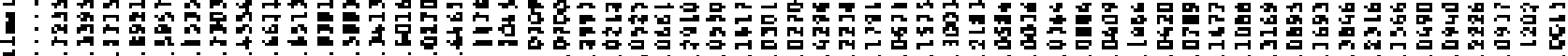

-

눈

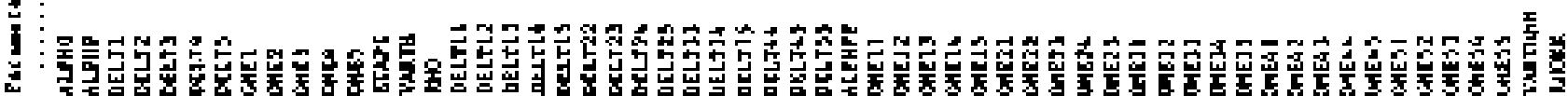




\section{Table 3}

\section{Composite CAMEL Rating}

Ordered Logit Regressions for the Full Sample of 356 Banks

and for the More and Less Efficient Halves of the Sample.

Dependent variable in all regressions is the composite CAMEL rating.

Standard errors in parentheses.

$* * *, * *, *$ indicate significance at the 1,5 , and 10 percent levels.

$\begin{array}{lll}\text { all banks } & \begin{array}{l}50 \% \text { most } \\ \text { efficient }\end{array} \quad \begin{array}{l}50 \% \text { least } \\ \text { efficient }\end{array}\end{array}$

(intercept terms concealed to preserve the confidentiality of exam ratings)

Assets (\$bill)

$\begin{array}{lll}.0239^{* * *} & -.0019 & .0244^{* * *} \\ (.0080) & (.0422) & (.0085)\end{array}$

Inefficiency

$.6631^{* *}$

$4.1645^{* *}$

.3926

(.3315)

(1.6834)

(.5069)

Risk

$1.8962^{* *}$

0.6016

$3.0392^{* *}$

(.8675)

(1.1225)

(1.2094)

Frontier Expected Return

$-3.0461^{* *}$

$-1.1059$

$-4.6117^{* *}$

(1.3556)

(1.7057)

(1.8920)

$\mathrm{N}$

356

178

178

chi-square statistic

for $-2 * \log ($ Lklihd $)$

$28.006^{* * *} \quad 9.092^{* *} \quad 24.214^{* * *}$




\section{Table 4 \\ Component CAMEL Ratings}

Ordered Logit Regressions for the Full Sample of 356 Banks. Dependent variable in all regressions are the CAMEL components.

Standard errors in parentheses.

$* * *, * *, *$ indicate significance at the 1,5 , and 10 percent levels.

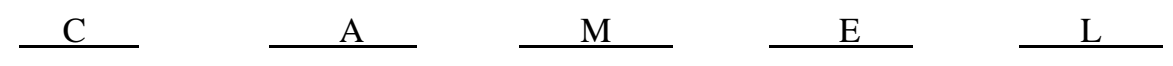

(intercepts concealed to preserve the confidentiality of exam ratings)

\begin{tabular}{|c|c|c|c|c|c|}
\hline Assets (\$bill) & $\begin{array}{l}.0344^{* * *} \\
(.0097)\end{array}$ & $\begin{array}{l}.0248^{* * * *} \\
(.0079)\end{array}$ & $\begin{array}{l}.0161^{* *} \\
(.0074)\end{array}$ & $\begin{array}{l}.0121^{*} \\
(.0068)\end{array}$ & $\begin{array}{l}.0317^{* * * *} \\
(.0087)\end{array}$ \\
\hline Inefficiency & $\begin{array}{l}-.8103^{* *} \\
(.3175)\end{array}$ & $\begin{array}{r}.3609 \\
(.3037)\end{array}$ & $\begin{array}{l}.9218^{* * *} \\
(.3295)\end{array}$ & $\begin{array}{l}1.6830^{* * * *} \\
(.3237)\end{array}$ & $\begin{array}{l}-.1464 \\
(.3088)\end{array}$ \\
\hline Risk & $\begin{array}{l}1.3511^{* * *} \\
(.5003)\end{array}$ & $\begin{array}{l}1.5474^{* *} \\
(.7822)\end{array}$ & $\begin{array}{l}.6600 \\
(.5310)\end{array}$ & $\begin{array}{l}1.1552 \\
(.7250)\end{array}$ & $\begin{array}{l}-.0773 \\
(.4827)\end{array}$ \\
\hline Frontier Expected Return & $\begin{array}{l}-1.5630^{* *} \\
(.6488)\end{array}$ & $\begin{array}{l}-2.4486^{* *} \\
(1.2060)\end{array}$ & $\begin{array}{l}-1.0523 \\
(.7130)\end{array}$ & $\begin{array}{l}-1.9894^{*} \\
(1.0984)\end{array}$ & $\begin{array}{l}.1882 \\
(.6270)\end{array}$ \\
\hline $\mathrm{N}$ & 356 & 356 & 356 & 356 & 356 \\
\hline $\begin{array}{l}\text { chi-square statistic for } \\
-2 * \log (\text { Lklihd })\end{array}$ & $29.908^{* * * *}$ & $24.994^{* * *}$ & $20.460^{* * * *}$ & $43.663^{* * *}$ & $15.648^{* * * *}$ \\
\hline
\end{tabular}

